S sciendo

10.2478/abcsj-2020-0015

\title{
Sea Imagery in Hala Alyan's Salt Houses
}

\author{
YOUSEF AWAD \\ University of Jordan, Jordan
}

\begin{abstract}
This article examines how Palestinian American novelist Hala Alyan employs sea imagery in her debut novel Salt Houses (2017) to reflect her characters' emotions and thoughts. In particular, this article shows that by examining a number of events in which characters are sitting by the sea or wading into the waters of the sea, the reader is given an insight into these characters' inner feelings and beliefs and the way they perceive their identities and contextualise their experiences as they move from one city to another. As the novel relates the narratives of four generations of a Palestinian family, sometimes using flashbacks, sea imagery increasingly occupies central positions in these narratives which reveal Alia's and her descendants' endeavours to express their opinions through memories and experiences of displacement, exile and estrangement. Although the title of the novel rightly heralds the significance of houses, it is the sea that forcefully emerges as a pivotal component in the narratives that these characters relate in their quests for a homeland that lives in the older generation's memories and the young people's imaginations. As Alia's granddaughter, Manar, visits Palestine in the final chapter of the novel and draws the family tree of the Yacoubs on Jaffa's beach, including her unborn baby, memories and imaginations merge to assert the right of Palestinians to "belong" to their homeland.
\end{abstract}

Keywords: Hala Alyan, Salt Houses, sea imagery, exile, Palestinian diaspora

\section{Introduction}

The houses float up to his mind's eye like jinn, past lovers. The sloping roof of his mother's hut, the marbled tiles in Salma's kitchen, the small house he shared with Alia in Nablus. The Kuwait home. The Beirut apartments. This house, here in Amman. For 
Alia, some old, vanished house in Jaffa. They glitter whitely in his mind, like structures made of salt, before a tidal wave comes and sweeps them away. (Alyan, Salt Houses 273)

On the seashore is a girl, and the girl has a family and the family has a house. [...] And in the sea is a warship having fun catching promenaders on the seashore:

Four, five, seven

fall down on the sand.

(Darwish, "The girl/The scream" 3)

Hala Alyan is a Palestinian-American poet and novelist. She has published four collections of poetry and a single novel, namely Salt Houses (2017). In her writings, she, like other Arab writers in diaspora, as Yousef Awad proposes, "foreground[s] a cross-cultural dialogue" in a way that reflects her position as an author who lives in the interstices of cultures (The Arab Atlantic 11). The novel relates the experiences of four generations of the Palestinian family of the Yacoubs who originally hail from the coastal city of Jaffa. The novel is narrated from the perspectives of several characters and portrays events between 1963 and 2014, sometimes using flashbacks. It opens with a depiction of the preparations for Alia's marriage to Atef in the Palestinian city of Nablus. After the Nakba of 1948 and the establishment of the state of Israel, Alia's parents, Husam and Salma, have been forced to leave their hometown of Jaffa along with their children, Widad, Alia and Mustafa. As the 1967 War breaks out, Mustafa and Atef are arrested by Israeli forces for their role in the armed resistance, whereas widowed Salma has by then relocated to Amman, and Alia has already left for Kuwait City to visit her sister.

Atef eventually joins his wife in Kuwait City and they are lulled into a more luxurious life with their children Riham, Karam and Souad. As years pass, Riham marries a Jordanian physician and relocates to Amman; Karam is sent to Boston to pursue his education, and Souad, in Paris for a summer school, gets married to childhood friend Elie and eventually joins Karam in Boston. As Iraqi tanks roll into Kuwait in 1990, Atef and Alia move to Amman. Years later, Souad and her children, Manar and Zain, head back to Beirut where they are joined every summer 
by other family members. Listening to her grandparents' accounts and recollections of their childhood memories in Palestine, Manar, an American citizen by birth, decides to visit her ancestors' homeland where she falls in love with the coastal city of Jaffa more than any other Palestinian city.

Although the title of Alyan's debut novel is Salt Houses, the cover of the British edition which was published by Hutchinson in 2017 is that of a seascape which is surrounded by oranges. The title of the novel is written in a dark orange colour in the centre of the cover while the name of the author is printed at the bottom of the cover in a lighter hue of orange. The image captures a seascape from the vantage point of the Palestinian coastal city of Jaffa, a city historically known for its staple fruit, the Jaffa orange. Even the spine of the book is orange. The novel vividly portrays the daily experiences of a displaced Palestinian family in different cities. However, the cover of the British edition of the novel emphasises the importance that sea imagery plays in the narratives of the four generations of the Yacoub family who originally hail from Jaffa. The quotation at the top of this article, voiced by Atef, Alia's husband, combines the two elements that permeate the family's multiple narratives: houses and the sea. These houses which are made of salt dissolve once they are hit by sea waves.

In fact, Atef's thoughts confirm the supremacy of the sea over the houses as the former constantly conquers the latter. The sea, that traditionally symbolises mobility and motion, wins over houses, which are symbols of fixity and stability. One may even view 'the sea vs. houses' dichotomy as a divide between exile and displacement on the one hand, and belonging and rootedness, on the other. As the characters move between Jaffa, Nablus, Kuwait City, Paris, Boston, Amman, Aqaba and Beirut, the sea occupies a central role in these characters' memories and imaginations. For the older generation, like Alia's, Jaffa's sea is lost forever and can be only preserved in her generation's memories. On the other hand, for the younger generation, like Manar's, Alia's granddaughter, Jaffa's beach is reachable by virtue of an American citizenship. It is in the final chapter that Alia's memories are unified with Manar's imaginings as the latter sits on Jaffa's beach and draws her 
family tree. In this way, not only is her ancestors' right to "belong" to their homeland asserted, but also her unborn baby's connections to this homeland. Between Alia's reminiscences and recollections and Manar's actual visit to Jaffa, the sea remains a powerful factor in the family's narratives as they move from one city to another in a never-ending tale of exile, displacement and estrangement.

The second quotation at the top of this article is from renowned Palestinian poet Mahmoud Darwish whose poetry Manar visualises herself reading in a seaside café in Jaffa. The extract itself reflects the importance of the sea in Palestinian cultural memory. The sea transported waves of Israeli settlers from Europe to Palestine since the turn of the nineteenth century. Therefore, in the collective Palestinian discourse, the sea is the source of violence against the Palestinians as the quotation from Darwish's poem demonstrates. At the same time, it is of paramount importance to understand how the sea, as Hannan Hever convincingly argues, is represented in the discourse of "the hegemonic Labor Zionist movement" in the early decades of the twentieth century (26). As Hever explains, "[t]he journey from Trieste to Jaffa was commonplace in Hebrew literature as the path of immigration to" the Holy Land (29). According to Hever, in the basic logic of a Zionist conceptualization of the sea, "the sea continues to function as bridge and passageway [...]. The sea is still mediator, the means of passage but not an end in itself" (29).

\section{Traditional Palestinian Society: Seaside Cities and Landlocked Villages}

Yet, one must be aware of the traditional structure of pre-Nakba (i. e. before the establishment of the state of Israel in 1948) Palestinian society and its attitudes towards the sea. In his seminal book Mountain against the Sea: Essays on Palestinian Society and Culture, Salim Tamari points out that the Palestinian society is mainly permeated by "the city village dichotomy" that was also "mediated through other identifications [...], mainly regional loyalties, religious affiliations, and clan affiliations" (5). Tamari argues that coastal Palestinian cities like Jaffa, Akka and Haifa "continued to evoke both hostility and fascination in the minds of the 
indigenous population of the interior" (23). Furthermore, the urban culture of these cities, "embodied everything the peasant feared might disrupt the traditional order" (23). In short, coastal cities represented "foreignness [...] as well as what the peasant desires most: freedom, escape from ruthless nature, and material advancement" (23). As Tamari's argument continues, Palestinian peasantry's fear of these coastal urban centres is embodied by the popular saying "'al-bahar ghaddar' (the sea is treacherous)" since it reflects "the peasant's hostility toward the unpredictable social forms that were emerging on the coastal plains" (24). However, by the turn of the nineteenth century, "tens of thousands of skilled workers from inland cities and peasant laborers migrated to the coastal region in cyclical waves, thus transforming not only their own lives, but also the social fabric of the coastal cities" (26).

In his discussion of pre-1948 Palestinian coastal culture, Tamari highlights two popular relationships with the sea that are not instrumental, as is the case with fishing and seafaring. The first example that Tamari gives is "the persistence of the ritual celebration of the sea (by a fertility cult), as peasants were transplanted from their agricultural environment to the seaside during the continued observance of Arbaat Ayyub" (34). The second example that Tamari discusses is "the modernist appropriation of the seashore by the urban masses [...] for recreational purposes" (34). He observes that both relationships have angered "retrogressive traditional forces attempting to maintain the regime of the virtuous" (34). In the first instance, "the ritual was condemned because it provided a form of mass psychotherapy outside the realm of formal, and therefore acceptable, religion," while in the second case, Tamari asserts, it "was considered to undermine the code of female modesty" (34) and explains that:

In a wider context, the treachery of the sea - which in peasant communities reflected the fear of uncontrollable nature - is now reconstituted to evoke anxiety about the uncontrollable and unanticipated impact of emancipated modernity, and of the presumably untamed and untamable sensuality of women. (34-35)

Coastal urban spaces witnessed a sea of change with the arrival of waves of Jewish immigrants from Europe to Palestine at the turn of the 
nineteenth century. As Nur Masalha explains, "most of the Jewish immigrants to Palestine, about 80 per cent, settled along the Mediterranean coast" (30-31). Similarly, Maurice Ebileeni argues that the establishment of the State of Israel and the consequent dispersion of Palestinians have deepened diversity among Palestinians and "have dispelled the sense of cultural homogeneity" (259). The coastal cities of Jaffa, Haifa and Acre "were largely depopulated. [...] Palestinian residents who remained were concentrated in poor neighbourhoods. Jaffa $[\ldots]$ was transformed from [...] a major and cosmopolitan export-import port, into a slum" (Masalha 7).

Since the Nakba of 1948, Palestinians have scattered all over the globe. Displacement, diaspora and exile are key features of a Palestinian's identity. In his seminal essay, "Reflections on Exile," Edward Said explains that exile "is the unhealable rift forced between a human being and a native place, between the self and its true home: its essential sadness can never be surmounted" (173). Said remarks that, despite the fact someone may successfully overcome impediments in exile, "[t]he achievements of exile are permanently undermined by the loss of something left behind forever" (173). Exile, as Said puts it, "is fundamentally a discontinuous state of being," and, therefore, exiles are cut off from their roots, their land, their past (177). This sense of loss leaves its mark on Alyan's characters who struggle, with different degrees of success, to fit into the spaces they occupy and the cities they live in. Significantly, the sea, both literally and metaphorically, emerges as a key dynamic that contributes to shaping these characters' daily experiences and questions of self-perception as they, willingly or unwillingly, change houses, re-adjust hopes and aspirations and cope with continually fluid circumstances and conditions.

\section{Oceanic Studies: The Sea as Metaphor}

In an article entitled "The Rise of the New Atlantic Studies Matrix," William Boelhower argues that "[t]he sea leaves no traces, and has no place names, towns or dwelling places; it cannot be possessed; it requires specific languages to be understood; and, above all, it has been 
traditionally considered the space of freedom par excellence" (92). Boelhower's words help explain the different ways that the sea is represented in literary texts. Sea voyages are recurrent motifs in epics, novels and poems. Authors like Homer, William Shakespeare and Daniel Defoe, to name just a few, have structured their narratives around sea voyages and maritime journeys. As Jonathan Raban succinctly puts it, "[t]he sea in literature is not a verifiable object, to be described, with varying degrees of success and shades of emphasis, by writers of different periods; it is rather, the supremely liquid and volatile element, shaping itself newly for every writer and every generation" (3). Indeed, the sea and seascapes in literary works have an infinite number of denotations and connotations. Seen from this perspective, one may argue that the sea can be a central "character" in narratives that revolve around themes and metaphors of nostalgia, exile, homelessness, loss, or escape.

In a similar vein, in her famous article "The Prospect of Oceanic Studies," Hester Blum insists that " $[\mathrm{t}]$ he sea is not a metaphor. Figurative language has its place in analyses of the maritime world, but oceanic studies could be more invested in the uses, and problems, of what is literal in the face of the sea's abyss of representation" (670). Blum advocates an approach that "draws from the epistemological structures provided by the lives and writings of those for whom the sea was simultaneously workplace, home, passage, penitentiary, and promise" (670). In other words, she draws attention to the material conditions and praxis of the maritime world in order to "allow for a galvanization of the erasure, elision, and fluidity at work in the metaphorics of the sea that would better enable us to see and to study the work of oceanic literature" (670).

Blum's suggestion has given rise to extended academic discussion on the need to take account of the sea and seascapes in literary, historical, cultural, and geographical studies. In "Of Other Seas: Metaphors and Materialities in Maritime Regions," Philip E. Steinberg "suggest[s] three, related alternative perspectives that directly engage the ocean's fluid mobility and its tactile materiality" (157). More specifically, Steinberg calls for "develop[ing] an epistemology that views the ocean as continually being reconstituted by a variety of elements: the non-human and the human, the biological and the geophysical, the historic and the 
contemporary" to fully appreciate the ocean as a uniquely fluid and dynamic space (157). Steinberg maintains:

I propose that, as part of the process of incorporating actual, lived experiences of the ocean into the studies of maritime regions, we need also to bring the ocean itself into the picture, not just as an experienced space but as a dynamic field that through its movement, through our encounters with its movement, and through our efforts to interpret its movement produces difference even as it unifies. (161)

Steinberg urges us to be attentive to the different and multiple questions, implications and associations that the sea can conjure up in literary, historical and social studies. As Steinberg argues, the movement of the sea should be studied from numerous angles and perspectives to deduce meanings and conclusions.

Steinberg's argument reiterates Boelhower's aforementioned proposal that because of the sea's "peculiarly critical nature, events and situations that take place within it are always phatic (performative) and uniquely hydrophanic - i.e. meaning is revealed through the agency of water" (92). Therefore, Steinberg encourages us to "turn to actual experiences of the sea, as have been chronicled by anthropologists, labor historians, and historical geographers, as well as in maritime or coastalbased fiction" (159). One may add to Steinberg's list novelists and poets whose literary texts portray adventurous and audacious sea voyages. Both Steinberg and Boelhower suggest that we scrutinize how the sea and seascapes are fundamental in understanding factual and fictional narratives in which the sea plays a major role. To put things in perspective, Steinberg's and Boelhower's stipulations have substantial implications for literary critics when investigating narratives that involve sea voyages and seascapes. This understanding enables literary critics to go beyond the traditional view of the sea as merely a setting or as a background. As Raban reminds us, "[t]he sea is one of the most 'universal' symbols in literature; it is certainly the most protean. It changes in response to shifts of sensibility as dramatically as it does to shifts of wind and the phases of the moon" (3). Heeding Steinberg's and Boelhower's suggestions opens new horizons to view the sea and 
seascapes as pivotal "players" whose roles should be fully contextualized and investigated in literary texts.

In Alyan's novel, the Mediterranean plays a central role, especially in pre-Nakba narratives that Alia and her husband Atef relate to their offspring. Listening to her grandparents' nostalgic accounts of Jaffa's sea, Manar decides to travel to Palestine to renew her family's connections with the Mediterranean. In "Mediterranean Ecocriticism: The Sea in the Middle," Elena Past describes the Mediterranean as "a material text into whose fabric are woven millennia of stories about the human relationship with the more-than-human world" (369). In developing a line of inquiry for Mediterranean ecocriticism, Past argues that the Mediterranean's waters "commingle people and things, as currents and winds, straits and deltas facilitate a slow but steady flux of matter and meaning" (370). Thus, Past calls for "a Mediterranean ecocriticism attentive to $[\ldots]$ the hybridities and crossings of Mediterranean politics, history, geology, and ecology" (371). A Mediterranean ecocriticism, according to Past, "proposes to read a host of texts [...] within this contested space" (371). It "de-centers the human role in Mediterranean history and articulates the ethical and material stories told by the more-than-human world" (371). Indeed, Alyan's novel, as the next section exemplifies, is replete with excursions, reminiscences, musings and hopes in which the very molecules of the Mediterranean caress characters, revive their memories and ignite their imaginations. In Salt Houses, as the title of the novel implies, houses are relentlessly swept away by sea waves. Mighty as it is, the sea in Alyan's novel is a refuge and a safe haven that preserves memories, shapes identities and concretizes fantasies.

Of Seas and Exile: Displacement, Identity and Belonging

Alyan's novel depicts the quotidian experiences of a number of Palestinian characters whose identities remain in a state of flux as they peregrinate from one city to another. Yet, one may convincingly argue that despite the state of displacement, unhomeliness and exile that these characters constantly undergo, it is the sea that anchors members of the Yacoub Family, connects them and brings them closer to their ancestral 
roots. Alia's granddaughter, Manar, visits Jaffa and draws her family tree on the beach, a scene which stands for the younger generation's resistance to Israeli attempts to uproot them and sever their ties with their motherland. Hence, this article will highlight how sea imagery underlies Alyan's representation of the Yacoub Family's exilic experiences. If Alia's union with the sea is cut off by her expulsion as a child from Jaffa along with her parents and siblings, Manar re-unites her grandmother with Jaffa's sea in defiance of Israeli attempts to wipe out the childhood memories of the Nakba generation. Moreover, Manar's act of resistance includes her unborn baby whose name she writes on Jaffa's beach.

In "Polyphonic Narrative Spaces in Hala Alyan's Salt Houses," Majed Aladylah argues that Alyan's novel "construct[s] a stable subjectivity and brings to the surface panoramas of Palestinian diasporas with various voices" (47). In his view, the novelist "employs different narrative techniques to convey the outlets of interior and exterior conflicted zones in hybrid and intercultural dislocations" (47-48). Furthermore, the narrative discourse "is constructed in a plethora of kaleidoscopic techniques that reflect social, cultural, familial and psychological dislocations" (47-48). Aladylah concludes that Alyan "amalgamates and juxtaposes" numerous voices of different generations and "open[s] up new spaces of existential consciousness to achieve selfdetermination, self-awareness and self-realisation within the dimensions of multiple voices and spaces" (51).

The first few pages of Alyan's novel draw the reader's attention to Salma's sense of dislocation and displacement in the "unfamiliar city" of Nablus since, fifteen years before, she was forced to flee Jaffa, her hometown, together with her husband and children (1). Salma describes her daughter, Alia, as "a child of war" since she was only three when the Israeli army invaded and occupied Jaffa, and Salma lost her villa that "sat atop a small hill that overlooked the sea" (5, my emphasis). Salma's bitterness at losing her house is linked to the loss of the sea that the house overlooks. Indeed, since 1948, as Masalha shows, "the Nakba has been central to Palestinian public memory and national identity" (11). To put things in context, Alia's father, Hussam, "refused to leave at first, shaking his fist at the sea and land outside their windows" (6, my emphasis). 
Hussam has become a "cheerless and short-tempered" person (6). One may understand Salma's and Hussam's disappointment and sense of unfamiliarity within the context of the social and cultural differences between Palestinian coastal cities and inland cities. As Tamari points out, "the intensification of trade and the rise of the new coastal bourgeoisie reinforced the differences between the coastal culture and the culture of the mountains" as Jaffa emerged as the cosmopolitan city of Palestine (26). Salma and Hussam's views of Jaffa are typical of the Nakba generation who tend "to freeze the homeland in a frame depicting a pastoral, idyllic lost paradise" (69).

The couple's loss of a house that overlooks the Mediterranean is a traumatic experience that has everlasting repercussions and ramifications. It passes from parents to children through nostalgic reminiscences of bygone times. Mustafa, Salma and Hussam's son, grows up in Nablus, but "ha[s] suffered from both the heavy burden of the Nakba experience and from the estrangement of exile" (69). Mustafa, Widad and Alia grew up with their parents' memories of loss. Here, one may draw on Marianne Hirsch's concept of postmemory to understand how the children were affected by their parents' reflections on the Nakba:

Postmemory most specifically describes the relationship of children of survivors of cultural or collective trauma to the experiences of their parents, experiences that they "remember" only as the narratives and images with which they grew up, but that are so powerful, so monumental, as to constitute memories in their own right. (9)

As the above quotation shows, postmemory is "an intersubjective transgenerational space of remembrance, linked specifically to cultural or collective trauma" (Hirsch 10). As children, Widad, Alia and Mustafa have repeatedly listened to their parents' stories about Jaffa's blue sea.

To invigorate his links with Jaffa, Mustafa makes a copy of a photograph of his father with "a view of the sea" from their old house in Jaffa and is told that "[t]he sea will be blurry" (33-34, my emphasis). The reply that Mustafa receives on the fuzzy image of the sea symbolically underpins the fact that the sea is slipping away, and the family's link with it is becoming a mere faint memory. Sea imagery is central to a story that Imam Bakri tells Mustafa as he successfully 
encourages him to join the armed resistance against Israel. Imam Bakri's story is about a fisherman's son who lived with his family by the sea. Then, the Israeli soldiers stormed their house and raped his sister. The family left two days later and moved to the hills: "As they left the little house, the sea didn't crash or froth to the shore. It just came, noiselessly, and went" (42-43). Imam Bakri tells Mustafa that the father has kept crying for the sea and he has even "'salted everything after that. Even his water. [...] When he died, he was buried beneath the hills he hated, far from the sea" (43). The image of the sea in Imam Bakri's story conveys themes of loss, exile and alienation.

In addition, the story that Imam Bakri tells Mustafa and in which "[t]he sea [is] like another member of the household, a recalcitrant child at times, a soothing aunt at others," is a story of thousands of Palestinians who were forced to sever their ties with the sea after the Nakba (41). As Masalha puts it, the "memory of pre-1948 life and the shock, devastation, humiliation and suffering wrought by the mass displacements of 1948 and 1967 [...] remain central to the Palestinian society of today" (14). The Nakba is a traumatic rupture that remains rooted in Palestinian collective memory (14). For Mustafa, Imam Bakri and many other characters in the novel who grew up by the sea, the Nakba is epitomized in the loss of the sea. This shows how in Alyan's novel the sea is a central element in narratives of exile, uprootedness and dislocation that the characters relate and pass to younger generations.

Hussam and Salma's sense of alienation after being forced to move away from the Mediterranean is passed down to their daughter, Alia. Visiting her sister Widad in Kuwait City in the summer of 1967, the year in which the remainder of Palestine was lost to the Israelis, Alia watches images beamed via televisions of Israeli fighter jets "screeching over the Mediterranean" (61). In other words, in Alia's consciousness, the loss of the rest of Palestine in 1967 echoes the loss of the Mediterranean in 1948. In the decade following the 1967 defeat, Alia lives in Kuwait City with her husband and children. Yet, she continues to cling to the hope of returning to her motherland one day and living close enough to the Mediterranean. But once she realizes that even this hope is diminishing, she rushes to Kuwait City's shoreline in an attempt to reconstruct her 
connections with Jaffa's sea: "The smell of the sea gusts into the open window. [...] The sound of the sea moves around them [...] For moments there is no sound aside from the thundering sea" (75). With its apparent uncontrollable and awe-inspiring power, the sea has an uplifting effect on Alia.

Gradually, Alia wades into the water and submerges herself in the sea. This has an instant influence on her:

She is glad. [...] At the rocks, she moves carefully, her shoes snagging in the crevices as they climb down. She [...] slips the shoes off, dangles them from her fingers. For a moment, $[\ldots]$ the sea $[\ldots]$ is suddenly everywhere, a living, snarling, barreling thing. Waves foam against the lip of the shore. (75-76)

Alia fully enjoys this experience and "laughs bitterly" although the water feels like ice (76). Alyan's representation of how Alia immerses herself in the sea is reminiscent of Steinberg's argument that the "liquid nature of the ocean at its center needs to be understood as emergent with, and not merely as an underlying context for, human activities" (159). This means that oceans and seas "need to be understood as 'more-than-human' assemblages $[\ldots]$ as they interact with and are co-constituted by the universe of mobile non-human elements that also inhabit its depths" (159). Seen from Steinberg's perspective, Alia's oneness with the sea connects her to her native Jaffa's sea, on the one hand, and gives her a feeling of serenity and composure, on the other. Indeed, this incident represents a turning point in Alia's life. In the sea, Alia reaches a state of equilibrium; she experiences jouisance.

Since her arrival in Kuwait City, Alia has felt detached and alienated. However, this experience has transformed her life:

The ocean rocks around them, the sand shifting beneath Alia's feet, a vertiginous sensation. Suddenly, a wave breaks, unexpected, sending them both stumbling backward. Water sprays, drenching Alia's dress, neck, hair. [...] 'So this is the beginning.' (75-76)

Alia is initiated into a life of exile and diaspora. She accepts her destiny as a displaced Palestinian who is doomed in exile. Significantly, it is this experience on Kuwait City's shoreline that makes her accept, albeit with 
bitterness and acrimony, this new beginning. Alia's relationship with Kuwait City's sea grows stronger as days, weeks, months and years pass.

Almost a decade on, the sea still has a lot more to reveal to Alia. One morning, after a round of grocery shopping in Kuwait City, "Alia changes her mind about going home and walks instead toward the sea" (152). Sitting on a bench in the marina with the water roiling in front of her, Alia meditates on how life has changed in Kuwait since she first arrived (152). She is later joined by a Kurdish girl named Telar who narrates to Alia how she and her family suffered in northern Iraq at the hands of Saddam's regime. Alia is sympathetic; she even conjures up memories of her own displacement: "Alia remembers her mother telling her, back in Nablus, that she used to cry for something when they left Jaffa. Though she cannot remember what. She has now forgotten twice" (156). By comparing her own experience to that of Telar's, Alia reminds us of Said's statement that in exile, "habits of life, expression, or activity in the new environment inevitably occur against the memory of these things in another environment" (186). Alia is unable to fully confront her loss of homeland. This conversation, which pointedly takes place by the sea, triggers Alia's memories of home and reminds her of loss and unhomeliness: "Next to Alia, Telar has fallen silent, watching the water" (156).

Alia's oldest child, Riham, truly senses her mother's and grandmother's nostalgic vulnerability. Listening to her grandmother's recollections of life in Palestine, Riham "loves to imagine the life her grandmother had, a peasant girl by the sea, before everything changed" (117, my emphasis). Just as the sea plays a fundamental part in the image that Riham pictures of her grandmother's childhood, it emphatically plays a major role in shaping Riham's future and the way she comes to perceive her identity. In one of the family's summer visits to the southern Jordanian coastal city of Aqaba, teenage Riham is encouraged by her mother to take a dip into the sea. Although Riham "is filled with hatred toward it," she wades deeper "until she - quickly - blankets herself with water" (124). Swimming, she remembers "her mother carrying her into the ocean as a child, a glimmer of seawater beneath her tiny hands" (124). 
Riham realizes that "the shore is now a blur - and panic begins to squeeze her" (125).

Gasping for air, Riham realizes that she is being pulled away from the shore. She forces her legs to kick and hears the screaming once more, falling and rising above the waves. This experience of drowning, makes Riham invoke Allah for help:

And with that fear Riham opens her mouth and speaks against the salt water the only name that leaps to her lips.

Allah.

Him, oh, Him, oh, that warm rush at the mosque, that hope that quickened her heart when her grandmother fitted the veil around her head. (127)

Eventually, a man saves her and brings her to the shore. Her grandmother reassures her that Allah has saved her, and Riham remembers, as her grandmother holds her, "[h]ow when the waves rocked her hard enough, she had called out for Allah and no one else" (130).

This incident has a perpetual effect on Riham's identity. When she grows up, she wears a veil, takes Islamic studies courses at the university, and begins to volunteer at a hospital. She eventually marries a Jordanian doctor, "an older religious widower with a young boy" (135). Years later, Riham recollects this drowning incident as a turning point in her life: "They [the refugees at her house's door] reminded her of the black splotch on her soul that she'd glimpsed that day - years and years ago - in the water, the ways in which she was impure. She has been scrubbing, after all. Every day since" (192). Thus, that incident in Aqaba had a great influence on Riham's identity, making her a devout practicing Muslim: "And then, years later, Riham wrapped faith around herself as effortlessly as a shawl, never once mumbling a complaint about rising early for prayer" (134-135). It is her experience of drowning in the sea that made her "wra[p] faith around herself" ever since. In this way, Riham becomes Souad's foil. Alia finds it hard to "make sense of it - the two daughters, years apart, one godless and unruly, the other veiled and earnest and married" (134).

The difference between Riham and Souad is also visible in their attitudes toward the sea. The omniscient narrator relates how Riham is 
reluctant to swim: "She eyes the water, dread knotting her stomach" (122). In contrast, Souad is eager to swim: "Souad stands up, all leg, sand sticking to her skin. She looks like a dirty, beautiful urchin in a Victorian novel" (122). As the two girls grow up, they choose two different cities to live in. Riham settles in landlocked Amman whereas Souad opts to reside in the coastal city of Beirut where she lives in an apartment "[n]ear the Corniche, $[\ldots]$ high enough [...] to glimpse the Mediterranean between telephone poles and buildings" (204). Years later in Beirut, Souad is still eager to take a dip into the Mediterranean: "Tomorrow she will swim, she decides, before summer is over. She will wear the black bikini she bought with Budur, will stay until the sun begins to set" (223-224). As Past rightly points out in her study of Mediterranean ecocriticism, we need to listen to "the hybrid, more-than human others whose complex voices and forces recount liquid stories that need our attention" (381). In this case, one should carefully follow Souad's love story with the sea which, one may argue, unfolds a cross-generational passion that she has inherited from her grandparents, Hussam and Salma.

Souad adores the sea, and so does her daughter, Manar. Listening to her grandparents' stories about their homeland, she becomes curious about visiting Palestine: "A part of her had fantasized that the trip would restore in her some faith, a land to which she'd feel unflinching attachment. [...] She'd envisioned reading Darwish in seaside cafés" (283). Manar's reference to Darwish's poetry is important since he himself is an exile whose poetry is permeated by sea imagery as the quotation at the start of this article indicates. As Aladylah puts it, "Salt Houses is like a dramatic poem in which the characters [...] dramatise recollections of experiences, past memories, multiple generations, conscious revelations and psychological lives" (47). When the plane begins to land in Tel Aviv Ben Gurion International Airport, "Manar presse[s] her forehead against the window, $[\ldots]$ the slate blue of the Mediterranean flicking against the shoreline" (283). Manar's aerial view mirrors what Alia watched on TV screens in the summer of 1967 as Israeli fighter jets "screech[ed] over the Mediterranean" (61). Yet, one may highlight substantial differences between the two situations. Alia is miles away from the Mediterranean at the time of watching the pictures that confirm it being usurped and 
snatched away from her as a Palestinian. By contrast, Manar's view is actual and carries undertones of a triumphant return to her homeland.

Manar's original plan was to visit her great grandparents' house in Nablus, which she read about in her grandfather's letters. Indeed, she finds the house, but she does not feel connected to it, nor even to the city of Nablus:

Nablus was the biggest disappointment of all. [...] Though her grandparents' stories were infrequent, this was where they grew up. [...]

A prickle of claustrophobia as the bus drove into Nablus - those endless cliffs and hills, the vast rising at either side. It made her feel caved in. Landlocked. (287-288, italics mine)

Manar is unable to connect with the city: "she just felt like an interloper, trespassing on memories that had nothing to do with her" (288). Tamari explains that "[i]n Palestine, most coastal towns did not look out toward the sea, but instead faced inland" (31). Moreover, these towns were built at a considerable distance from the sea, and all village houses were built facing east, with their backs toward the sea, ostensibly to be protected "from the western winds and their humidity, but the social consequences of this orientation cannot be underestimated" (31). Yet, Tamari insists that "the situation in Jaffa [...] was exceptional" (31). This probably explains Manar's unplanned decision to visit Jaffa: "The city has a pacifying effect on her, the shoreline jutting out to meet the sea. The city is worn, shabby but enchanting, the walls scribbled with graffiti. Up close, Jaffa shows its age" (288). The contrast between landlocked Nablus and seaside Jaffa cannot be emphasized enough.

In Jaffa, Manar feels at home. Alyan's depiction of Manar's unrestrained passion for the coastal city of Jaffa in contrast to her detachment from the interior city of Nablus may be understood as writing back to Zionist narratives of the Mediterranean. Specifically, Hever argues that a recurring Labor Zionist narrative "emphasized estrangement from the sea: the sea functions only as a mirror image of territory since what is important $[\ldots]$ is not the sea but the passage via the sea" to the Holy Land (27). Hence, in the Labor Zionist discourse, "the sea is represented through the mythological voyage from eastern Europe by way of Trieste in Italy to the port of Jaffa in Palestine" (27). In other words, 
the sea functions as a window for looking onto what lies beyond it, namely, Palestine (28). Hever concludes that "the Mediterranean culture of Israelis is European and not Arab, the ocean a smooth connection between Europe and Israel" (40). Seen from this perspective, the way Manar interacts with the sea is highly symbolic as it represents a Palestinian counter narrative to the Israeli narrative.

Manar fully enjoys the Jaffa sea experience. She has dinner in a restaurant overlooking the Mediterranean where "[t]he view is astounding" (276). Manar is in full harmony with the seascape as "[t]he sun dips into the sea" (278). She is "aware of how sensual the air feels, the beauty of the seascape around her" (278). When she finishes her dinner, she leaves the restaurant but she "[s]uddenly ach[es] for the sea, she walks the narrow streets, $[\ldots]$ and there, pale in early light, the water waits" (298). Looking at the sea, Manar feels the urge to document this moment:

Jaffa. There is that desire, the old wanting, to say something. For someone to bear witness as she speaks.

Bits of shells and pebbles pierce her feet along the sand, a cool relief as her toes touch water. She takes a breath. [...]

Sobering, she walks along the shoreline, the water icy against her ankles. (295)

Alyan's depiction of Manar's oneness with Jaffa's sea echoes Alia's earlier transcendent experience on Kuwait City's shoreline in 1967. However, if Alia's experience has initiated her into a life of exile and displacement, Manar's, by contrast, has cemented her ties with her motherland and reinforced her sense of belonging.

Thus, one may argue that Alyan's representation of the sea, to quote Steinberg's words, "disassembles accepted understandings of relations between space and time, between stasis and mobility, and between human and non-human actants" (165). Alyan's depiction, to refer to Steinberg once more, "engag[es] with the ocean in all its material complexity [... and] develop[s] the fluid perspective that allows us to use the sea to look beyond the sea" (165). Seen from Steinberg's perspective, one may argue that Manar is not only enjoying herself on the seashore, but she is also reconstructing the unique relationship between her ancestors and the sea, a link that she has become familiar with through the countless tales she 
repeatedly heard from her grandparents, Atef and Alia. Just like her grandmother, Manar experiences a sublime feeling that offsets the estrangement that she experiences in Nablus: "It is beautiful, all of it - the hastening of the waves, how the water gathers itself as though spilling white petals onto the sand. [...] Her tired mind alights on myths - Midas, Icarus, the stories she spent years memorizing. Everything she has forgotten" (295). Manar is rejuvenated; her memory is refreshed. Once she feels connected to the sea, Manar decides to write "[a] testimony" (296). She begins to draw her family tree on the wet sand.

Manar's act of drawing epitomizes a spirit of defiance and resistance. By drawing her family tree on Jaffa's beach, Manar is asserting her family's right of belonging to Jaffa: "Alia, she traces. Alia Yacoub. She pauses, considering. Atef Yacoub. [...] A family tree. Riham, Karam, Souad, she traces. [...] Abdullah, Manar, Linah, Zain" (296). Manar challenges Israeli attempts to sever the ties between Palestinians and their homeland: "Looking at the names, she speaks again. 'We were all here.' [...] She imagines her whole family standing on this shoreline, in a row. Oddly cheered by the image, she pulls her knees to her chin and muses to the waves, "Even you, Teta [Alia]"' (296). Interestingly, she draws a family tree of four generations of Palestinians, including her unborn baby girl: "She draws a final line from her own name. Gabriel. Below, an arrow that leads to a small question mark. Leah? June? Dara? There is a human, she realizes, that she will have to name" (296). Alyan's portrayal of Manar's experience on Jaffa's coast reminds us of Steinberg's comment that focus should be extended to "the materiality of the coast" beside the materiality of the ocean itself (163). The coast here is not merely a space, it is a witness to a cross-generational loving attachment to the sea. Manar's visit to Jaffa does not only fulfil her original plan of "reading Darwish in seaside cafés" (283), but it also enables her to assert her links to Palestine and ancestral affections to the blue Mediterranean.

\section{Conclusions}

In his critical analysis of Salt Houses, Aladylah rightly shows that in Alyan's novel "the social and dialogical narrative discourse and the 
polyphonic voices are structured around experiences of dislocation, diaspora, exile, home and relocation" (46). This polyphony is, ironically, tuned and harmonized by the thunderous voice of the sea. The sea is a prominent actant in the narratives that these characters relate and pass from one generation to another. The sea, as Steinberg succinctly puts it, "is a space of circulation because it is constituted through its very geophysical mobility" (165). Steinberg insists that not only is the sea "a space that facilitates movement - the space across which things move but it is [... also] a space that is constituted by and constitutive of movement" (165). Hence, the sea merits greater attention in our literary, historical and social studies. In Alyan's novel, the movements of the characters reflect those of the seas and oceans they navigate and traverse as they attempt tirelessly to find houses that will not dissolve. Renowned Palestinian thinker Said remarks that "[e]xile is [...] nomadic, decentered, contrapuntal; but no sooner does one get accustomed to it than its unsettling force erupts anew" (186). As houses collapse and vanish into thin air, the Yacoubs find out that the sea is more reliable and trustworthy since the family builds its house by Kuwait City's shoreline, which helps them survive and thrive.

As Hussam and Salma are forced to sever their ties with the Mediterranean in 1948, their great granddaughter, Manar, restores these links in 2014 as she visits Jaffa by virtue of her American citizenship. For more than sixty years, the Yacoubs have lived as exiles and wandered between Nablus, Kuwait City, Amman, Beirut, Paris and Boston. Exile, to quote Awad's words on diasporic Palestinian literature, "is woven into the novel's fabric," gets under some characters' skins, "shap[es] their identities by reminding them of the past trauma(s), outlin[es] their present experiences and $\operatorname{draft}[\mathrm{s}]$ their prospective plans" ("Displacement, Belonging and Identity" 2). As Said reminds us, "a life of exile moves according to different calendar, and is less seasonal and settled than life at home" (186). Yet, the sea has played a vital role in the Yacoubs' nomadic life. Accepting her fate as a displaced Palestinian, Alia, Hussam and Salma's daughter, takes refuge in Kuwait City's sea as she recollects bittersweet memories of her parents' house by Jaffa's sea. Alia's elder daughter, Riham, wraps herself in a sea of faith and settles to the life of a 
quiet housewife after almost drowning in Aqaba's sea. Souad, Alia's younger daughter, is another lover of the sea who, upon returning from Boston, lives in a seaside apartment in Beirut. Still, it is Souad's daughter, Manar, who merges her grandmother's memories with her own imaginings by drawing her family tree on Jaffa's shoreline, which stands proof of the circularity put forth in the novel. The wheel has come full circle; the novel ends where it begins.

\section{Works Cited}

Aladylah, Majed. "Polyphonic Narrative Spaces in Hala Alyan's Salt Houses." Critical Survey 31.3 (2019): 44-52.

Alyan, Hala. Salt Houses. London: Hutchinson, 2017.

Awad, Yousef. The Arab Atlantic: Resistance, Diaspora, and Trans-Cultural Dialogue in the Works of Arab British and Arab American Women Writers. Rīgā: Lambert, 2012.

---. "Displacement, Belonging and Identity in Susan Muaddi Darraj's The Inheritance of Exile." Studies in Literature and Language 10.2 (2015): 1-10.

Blum, Hester. "The Prospect of Oceanic Studies." PMLA 125.3 (2010): 670-677.

Boelhower, William. "The Rise of the New Atlantic Studies Matrix." American Literary History 20.1-2 (2008): 83-101.

Darwish, Mahmoud. A River Dies of Thirst: Journals. Trans. Catherine Cobham. Brooklyn, NY: Archipelago, 2009.

Ebileeni, Maurice. "Palestinian Writings in the World: A Polylingual Literary Category Between Local and Transnational Realms." Interventions: International Journal of Postcolonial Studies 19.2 (2017): 258-281.

Hever, Hannan. "The Zionist Sea: Symbolism and Nationalism in Modernist Hebrew Poetry." Jewish Culture and History 13.1 (2012): 25-41.

Hirsch, M. "Surviving Images: Holocaust Photographs and the Work of Postmemory." The Yale Journal of Criticism 14.1 (2001): 5-37.

Masalha, Nur. The Palestine Nakba Decolonising History, Narrating the Subaltern, Reclaiming Memory. London: Zed, 2012.

Past, Elena. "Mediterranean Ecocriticism: The Sea in the Middle." Handbook of Ecocriticism and Cultural Ecology. Ed. Hubert Zapf. Berlin: De Gruyter, 2016. 368-384.

Raban, Jonathan. The Oxford Book of the Sea. Oxford: Oxford UP, 1993.

Said, Edward W. Reflections on Exile and Other Literary and Cultural Essays. London: Granta, 2000.

Steinberg, Philip E. "Of Other Seas: Metaphors and Materialities in Maritime Regions." Atlantic Studies 10.2 (2013): 156-169.

Tamari, Salim. Mountain against the Sea: Essays on Palestinian Society and Culture. Berkeley, CA: U of California P, 2008. 